3-10-2003

\title{
What Kind of Nation Thomas Jefferson, John Marshall, and the Epic Struggle to Create a United States (2003)
}

James F. Simon

New York Law School, james.simon@nyls.edu

Follow this and additional works at: https://digitalcommons.nyls.edu/fac_books

\section{Recommended Citation}

Simon, James F., "What Kind of Nation Thomas Jefferson, John Marshall, and the Epic Struggle to Create a United States (2003)" (2003). Books. 117.

https://digitalcommons.nyls.edu/fac_books/117

This Article is brought to you for free and open access by the Faculty Scholarship at DigitalCommons@NYLS. It has been accepted for inclusion in Books by an authorized administrator of DigitalCommons@NYLS. 


\section{What Kind}
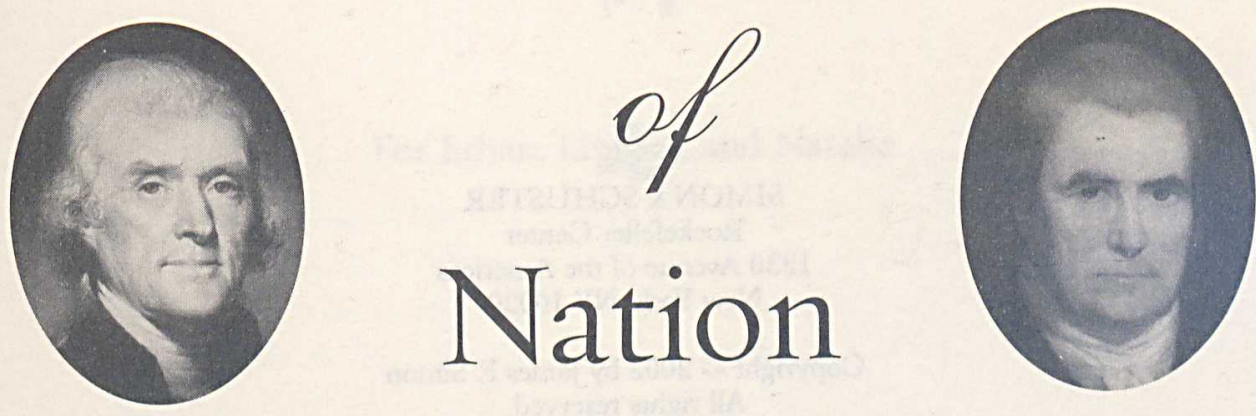

\section{Thomas Jefferson, John Marshall, and the Epic Struggle to Create a United States}

\section{James F. Simon}

SIMON \& SCHUSTER

New York London Toronto Sydney Singapore 

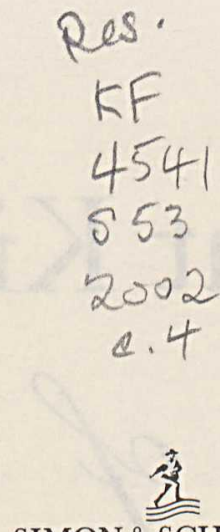

SIMON \& SCHUSTER

Rockefeller Center

1230 Avenue of the Americas

New York, NY 10020

Copyright (C) 2002 by James F. Simon

All rights reserved, including the right of reproduction in whole or in part in any form.

SIMON \& SCHUSTER and colophon are registered trademarks of Simon \& Schuster Inc.

Title page illustrations:

Portrait of President Thomas Jefferson (detail) by Rembrandt Peale, (C) Bettmann/Corbis; Portrait of John Marshall (detail) by Edward F. Peticolas,

Kirby Collection of Historical Paintings, Lafayette College, Easton, PA

For information regarding special discounts for bulk purchases, please contact

Simon \& Schuster Special Sales at 1-800-456-6798 or business@simonandschuster.com

Designed by Deirdre Amthor

Manufactured in the United States of America

$\begin{array}{llllllllll}1 & 3 & 5 & 7 & 9 & 10 & 8 & 6 & 4 & 2\end{array}$

Library of Congress Cataloging-in-Publication Data

Simon, James F.

What kind of nation : Thomas Jefferson, John Marshall, and the epic struggle to create a United States / James F. Simon

p. $\mathrm{cm}$.

Includes bibliographical references and index.

1. Constitutional history-United States. 2. Political questions and judicial powerUnited States-History. 3. Executive power-United States-History. 4. United States.

Supreme Court-History. 5. Jefferson, Thomas, 1743-1826. 6. Marshall, John, 1755-1835. 7. United States-Politics and government-1783-1809. I. Title. 


\section{Contents}

I. "Swindling Propositions" 39

2. "The Reign of Witches" 49

3. A Sense of Duty 63

4. Defending the President 85

5. Prelude to a Revolution $\quad$ IO4

6. "The Fangs of Jefferson" II8

7. "The Least Dangerous" Branch 138

8. Mr. Marbury's Missing Commission $\quad$ I73

9. A "Bungling Way" to Remove Judges I9I

IO. Treason Against the United States 220

II. Final Battles 260

EPILOGUE

SOURCE NOTES $\quad 303$

ACKNOWLEDGMENTS $\quad 327$

INDEX $\quad 329$ 


\section{Prologue}

The American Minister to France, Thomas Jefferson, had loathed George III from afar for years. Almost a full decade earlier, the thirtythree-year-old Jefferson had denounced the British monarch: usurper, plunderer, oppressor. Had his draft of the Declaration of Independence not been edited by the Continental Congress, it would have added that the king of England "waged cruel war against human nature itself."

On March 17, 1786, Jefferson waited at the Court of St. James's to meet the English king. He was accompanied by another hero of the American Revolution, his close friend John Adams, the American minister to Great Britain. They hoped to negotiate a commercial treaty between Great Britain and her former colonies. Jefferson was no longer a young American revolutionary, but a prominent member of an independent government's diplomatic corps. And though the United States was a struggling young confederation, no match in political, economic, or military might for Great Britain, Jefferson expected to be treated with the respect due a representative of a sovereign nation.

At noon on that March day, George III entered the palatial chamber where Jefferson and Adams waited with other foreign envoys to be formally presented. Neither Jefferson nor Adams recorded the event in letters or journals at the time. But as an old man, Jefferson recalled with bitterness the moment that he was introduced to the British king. 
Nothing could have been more ungracious, Jefferson remembered, than his introduction to King George and Queen Charlotte. The king barely acknowledged Jefferson's presence, which may have had something to do with the monarch's low regard for the author of the Declaration of Independence.

Adams's grandson, the historian Charles Francis Adams, later provided a vivid explanation for Jefferson's reaction. Upon his grandfather's presentation of Jefferson to the king and queen, they rose from their chairs and turned around so that the two American ministers were faced with their royal posteriors.

Jefferson's sour memory of the event is more important than the fact that modern historians have poked large holes in both Jefferson's and Charles Francis Adams's versions of the event. It is improbable that Queen Charlotte was present in court that day, since, by tradition, George III presided alone at the twice-weekly levees such as the one attended by Jefferson and Adams. The king's practice, moreover, was to greet visitors during a "walkabout" of the room, much as contemporary leaders of state customarily do at official ceremonies. If that was the case, it would have been virtually impossible for King George to turn his back on Jefferson without performing an abrupt about-face, an exercise that no one claimed to have witnessed.

Details aside, Jefferson's antipathy for Great Britain's monarch was real enough, and enduring, as was his abiding mistrust of the motives and policies of His Majesty's government. Those feelings were reinforced when he and Adams met with the marquis of Carmarthen, the English secretary of state for foreign affairs, to work out the terms of a commercial treaty.

Before their meeting with Lord Carmarthen, Adams and Jefferson had discussed the terms that might be included in an agreement. At the instruction of Congress, Adams had already proposed that the resolution of political issues be a part of any commercial treaty. Specifically, Adams requested that any settlement of outstanding claims of British creditors against Americans be combined with an agreement that the British relinquish their military outposts in the old Northwest Territory (as yet, an unfulfilled promise of the 1783 Peace Treaty). Adams had also asked that Great Britain provide financial compensation for slaves and other property expropriated by British troops during the Revolu- 
tionary War, a demand of more than diplomatic concern to Jefferson.

While governor of Virginia in 1781, Jefferson was not only forced to retreat from the temporary state capital of Charlottesville by invading British troops, but later discovered that General Cornwallis's soldiers had overrun his Monticello estate, absconded with thirty of his slaves, and burned his entire year's crop of tobacco. Jefferson did not dwell on those past grievances in his strategy session with Adams, or, for that matter, on his steadily mounting debts to British creditors. He focused on general negotiating points, insisting that any treaty include not only absolute commercial reciprocity between the two nations but the exchange of citizenship rights, so that Americans and the British would each enjoy the same protections on the other's soil.

Adams and Jefferson made the oddest of diplomatic couples, both in physical stature and temperament. Adams was short (five feet seven inches), plump, and naturally combative; Jefferson stood over six feet two inches, was lean and long-limbed, and projected an air of cool detachment. Once the American ministers began their, discussions with Lord Carmarthen, it became immediately apparent that neither their diplomatic skills nor their careful preparations would be rewarded. The British secretary of state wasted no time in informing the Americans of the cold facts of life between two such unequal nations. He made clear that His Majesty's government would dictate the terms of any treaty, and quickly ruled out any discussion of political issues. The British secretary's tepid attempts to respond to Adams and Jefferson's trade proposals were so vague and evasive, Jefferson observed, that he could not have been serious about an agreement.

In the weeks that followed, Jefferson's initial pessimism deepened. After he and Adams received word that the British Foreign Office would entertain a redrafted proposal from the Americans limited to commercial subjects, Adams and Jefferson worked furiously overnight to rewrite their previously submitted treaty terms. Lord Carmarthen did not respond, though he knew that Adams's and Jefferson's congressional commissions to reach agreement on a treaty were to expire by the end of May.

Later, Jefferson concluded that the British government had never intended to sign a trade treaty with the United States. This was made obvious from the dismissive treatment that he and Adams had received 
at Whitehall, which, Jefferson surmised, was rooted in British arrogance and the conviction that the British had nothing to gain from a treaty with the fledgling nation.

Lord Carmarthen's attitude toward the American ministers reflected the British assessment of the international status of the new nation they represented. The United States had signed a peace treaty with Great Britain three years earlier, but the end of hostilities had not brought Americans power, prosperity, or, in truth, genuine independence. The mother country still dominated her former colonies, not so much by the sword as by the purse. With Americans' appetite for British manufactured goods, the balance of trade tilted overwhelmingly eastward. And Great Britain did not hesitate to press her advantage. She continued to seal off American goods from the lucrative British West Indies market, while her superior navy patrolled the commercial corridors of the Atlantic and the Caribbean.

Jefferson suspected that there was more to the rough British treatment that he and Adams received than diplomatic calculation. "That nation hates us," Jefferson wrote, "their ministers hate us, and their king, more than all other men."

That harsh assessment was more than reciprocated. Jefferson detested the hauteur that permeated the high echelons of British government and society, and speculated that perhaps it had something to do with their unbalanced, meat-heavy diet. Nor did he like the cold, damp British climate. And he found London's architecture positively "wretched."

Jefferson could not deny, of course, that the British had made significant contributions to Western civilization, and during his seven-week visit, he took full advantage of what the nation had to offer. John and Abigail Adams escorted him to the British Museum and to Covent Garden, where he attended performances of Macbeth and The Merchant of Venice. He made the requisite tourist's pilgrimage to Shakespeare's birthplace at Stratford-upon-Avon (and recorded the price of admission: one shilling). Adams organized for his guest an extended tour of British estates and gardens, which Jefferson judged superior to any that he had seen in France or the United States. With notebook in hand and a copy of Thomas Whateley's Observations on Moder Gardening in his pocket, he took copious notes on his own observations, and later 
appropriated some of the best ideas for his home and gardens in the Virginia mountains.

No nation, Jefferson admitted, could compete with the British for ingenious mechanical innovations. He was awed by the steam-powered grist mill at Blackfriars on the Thames and predicted that the newly discovered source of energy would soon propel ships. He marveled at a portable copying press that could instantly replicate a letter and bought one for himself, as well as several other gadgets, including a solar microscope, a globe telescope, a protractor, and a thermometer. And, with Abigail Adams, he shopped and shopped, purchasing a new suit, a carriage and plated harness, and a harpsichord for his fourteenyear-old-daughter, Patsy.

For all of the private pleasures that London and the English countryside had provided him, Jefferson was delighted to return to Paris. Among the nations of the world, France had occupied a special place in Jefferson's head and heart since the Revolution, when she gave critical support to the Americans against the British. France offered true heroes to match America's own, such as the brave young nobleman the General Marquis de Lafayette. Jefferson and Lafayette were the best of friends in Paris, where the Frenchman proudly displayed a framed copy of the Declaration of Independence in his study. As Jefferson's most valued political adviser, Lafayette helped the American minister navigate the labyrinthine French governmental bureaucracy. And Jefferson needed all the help he could get as he attempted, with only modest success, to persuade the government to lower the high tariffs on American goods.

By 1786, there were faint rumblings that the French government faced impending bankruptcy and that Louis XVI was incapable of managing a financial crisis or the rising public unrest. Jefferson remained confident that crisis could be averted and that peaceful accommodation could be reached among the king, the nobles and clergy, and the commoners.

In general, Jefferson's attitude toward life and politics had become noticeably more sanguine in Paris, where the gaiety and sophistication of the French had provided the perfect elixir for his low spirits when he 
arrived in 1784 as minister plenipotentiary to France. At that time, Jefferson's suffering was due to excruciating disappointment and loss that had beset him in Virginia. In 1781, the state legislature had called for an official investigation into his behavior as wartime governor. His detractors charged that he had acted both irresponsibly and cowardly, first, in not making necessary preparations to defend the state, and then in fleeing from invading British troops. Although no investigation ever occurred, Jefferson felt compelled to justify his actions in a powerful speech on the floor of the House of Delegates. But the bad taste of the accusations lingered. And the next year, Jefferson's wife, Martha, died following the birth of their sixth child. Her death left him griefstricken and responsible for the care of their three surviving children.

Once he had settled into his residence at the Hôtel de Langeac, a spacious three-story villa near the Champs-Élysées, Jefferson's spirits demonstrably brightened. In contrast to his decidedly negative views of the British, Jefferson admired the polite manners and contagious conviviality of the French. He loved their cuisine and fine wines, their stimulating salons and plentiful evening concerts. And he was so impressed by the classical Roman architecture in France, particularly the Maison-Carrée at Nîmes, that he successfully implored Virginia's directors of public buildings to change the design of the state capitol, after the foundation had been laid, to emulate the Nîmes model.

Jefferson had promised his wife on her deathbed that he would never remarry. We now know that he later engaged in a lasting relationship with his beautiful young slave, Sally Hemings, who joined his staff of servants in Paris. And while in the French capital, Jefferson courted Maria Cosway, the enchanting wife of the British miniaturist Richard Cosway. For six weeks in the late summer and fall of 1786, Jefferson and Maria were virtually inseparable, touring galleries, attending concerts in the Tuileries, and strolling in the Bois de Boulogne. Later, Jefferson's ardor for Maria cooled, though they remained friends and long-distance correspondents for decades.

As enamored as Jefferson was with his life in Paris, he kept close tabs on political developments in the United States, primarily through regular correspondence with his Virginia ally, James Madison, who in the summer of 1787 was a delegate to the Constitutional Convention in Philadelphia. Jefferson and Madison had served together in Virginia's legislature. Both men had understood their collaborative roles: Jefferson 
was the visionary whose ideas and lilting phrases breathed life into the abstract demands for individual rights and liberties. He valued Madison for his extraordinary intellect and shrewd judgment. A subtle, sophisticated political thinker, Madison knew how to translate Jefferson's grand concepts into law. An early example of their successful joint efforts was the passage of the Virginia Statute for Religious Freedom, which called for a strict separation between church and state. Jefferson had contributed the eloquent draft; Madison had devised the winning legislative strategy and, in the process, offered his own brilliant defense of religious liberty.

Madison had much to report to Jefferson after the convention in Philadelphia. The document reflected Madison's and the other framers' commitment to representative democracy under a tripartite federal system. But throughout the document, there were compromises, both among the three branches of the federal government and between the federal government and the states. After the struggle for passage at the Constitutional Convention, Madison and other Federalists knew that they faced formidable opposition to ratification by the states. It would be led by Anti-Federalists, who continued to object to the substantial power given to the federal government at the expense of the states, as well as the absence of a Bill of Rights.

Madison could not have been happy, then, that Jefferson's initial reaction to the document he had worked so mightily to create was unenthusiastic. At first, Jefferson expressed disappointment that a few provisions had not been added to the old Articles of Confederation, which gave the dominant government power to the states, rather than replacing the entire document. With memories of the British monarchy still fresh, Jefferson worried that the renewable four-year term for the U.S. president invited monarchy by another name. Once a president was elected to office, Jefferson feared, he could control the levers of power so that he effectively could hold office for life. Jefferson also shared the Anti-Federalists' concern that the Constitution did not include a Bill of Rights to protect individual citizens from the potential tyranny of a powerful central government. To make matters worse for Madison, reports of Jefferson's reservations about the document circulated publicly and were eagerly repeated by Anti-Federalist leaders, such as Virginia's great orator Patrick Henry, who urged his state's delegates to vote "no" on the Constitution. 
By the time Virginia's delegates convened in Richmond on June 2, 1788, to vote on the Constitution, eight states had already approved the document, one short of the number needed for ratification. But the numbers were deceptive and did not guarantee ultimate success. In fact, the Constitution had stirred fierce opposition, even in states that, like Pennsylvania, the Federalists had considered safely in their column. And now came the battle for Virginia, the nation's most populous and prosperous state. The most influential native son, George Washington, was fully supportive of the Constitution. But he was not in Richmond and could only offer his encouragement by letter to Madison, who directed the Federalist forces. That Jefferson was also absent was not necessarily detrimental to the Constitution's cause, given his stated ambivalence about the document. There was, to be sure, talent enough to make the case for the Constitution. Besides Madison, the Federalists could call upon leaders of the Virginia bar, including Governor Edmund Randolph, the venerable advocate Edmund Pendleton, and a thirty-two-year-old Richmond lawyer named John Marshall.

The Virginia Anti-Federalists were well equipped to challenge the formidable Madison and his allies. They were led by Patrick Henry, the more cerebral member of the Virginia establishment, George Mason, and Jefferson's protégé, James Monroe, who provided multiple reasons for the delegates to reject the Constitution. The debate raged over three weeks in a two-year-old wooden building known as the New Academy, where the cramped, sweltering delegates traded barbs and arguments in the sultry June heat. Throughout the sessions, Madison remained apprehensive about the Federalists' chances of success. The main reason for his trepidation was the opposition of Henry, whose impassioned arguments continually captivated the convention. If Henry's rhetorical spell over wavering delegates was sustained, the powerful and influential state of Virginia would reject the Constitution, and the ninth and crucial vote for ratification might never be cast.

Once he had the floor, Henry, stooped, bespectacled, and looking much older than his fifty-two years, wasted no time in striking the most fearful chord of the Anti-Federalists. "The question turns," he 
said, "on that poor little thing-the expression, 'We, the people; instead of the states." "With that sly elusion, Henry suggested, the Federalists had imperiled everything that the colonists had fought for, not just the sovereignty of the states but also individual liberties. The confederation of the states, he reminded his opponents, had won the War of Independence. And for what? To be replaced by an all-powerful central government that "will oppress and ruin the people." The Constitution "squints toward monarchy," Henry declared. "Your President may easily become a king," he continued, raising the issue that had alarmed Jefferson. Henry accused the framers of eviscerating the executive and legislative powers of the states. And with the creation of a federal judiciary, "the scales of justice are to be given away." Do not abandon the Articles of Confederation, he pleaded, claiming that no less a patriot than Thomas Jefferson agreed with him. "It [the Confederation] rendered us victorious in that bloody conflict with a powerful nation. It has secured us a territory greater than any European monarch possesses. And shall a government which has been this strong and vigorous be accused of imbecility and abandoned for want of energy?"

Madison was no orator and wisely decided not to try to compete with Henry's pyrotechnics. Small, pale, and with a weak, reedy voice, he addressed the delegates in a conversational, diffident manner, holding his hat (which contained his notes) in his hand. Madison never overwhelmed an audience. But no one knew the intricacies of the Constitution better than he. Over the course of the three-week debate, Madison methodically laid out the case for a constitution, delivering, in effect, a comprehensive treatise on the document.

Slowly, Madison proceeded to undercut Henry's argument that the framers had created a federal engine for oppression. The overriding purpose of the Constitution was to provide an effective governing structure for a representative democracy. The people were protected through the system of checks and balances among the three branches of the federal government. Taking the Constitution as a whole, Madison insisted that there was ample protection against monarchy in the office of the presidency or the accumulation of imperious powers by Congress or the federal judiciary. And the states remained sovereign, he reminded the delegates, on issues that did not concern the federal government. 
As to the need for a Bill of Rights, Madison argued before the convention, as he did privately to Jefferson, that the Constitution did not give the federal government authority to intrude on the individual liberties of citizens, and that therefore explicit guarantees were unnecessary. He rejected Henry's suggestion that the Constitution should be amended to include a Bill of Rights before ratification. Ratify first, said Madison, adjust for imperfections in the document later.

Madison noted to the delegates that Henry had invoked Jefferson's name. Mr. Jefferson endorsed many of the Constitution's provisions that Anti-Federalists claimed he opposed, Madison said, an assurance that was backed by Jefferson's statements in his private correspondence with Madison. Despite his reservations, Jefferson had ultimately agreed with Madison on the need for ratification. And Madison accepted Jefferson's argument that there must be a Bill of Rights, which Madison later drafted.

Pendleton and Randolph also hammered away at the Anti-Federalists' arguments against ratification. But the outcome was still in doubt when the Federalists called upon the services of young John Marshall. Marshall had only been practicing law for five years and did not enjoy the stature in the legal community of Randolph or Pendleton. But he was a Revolutionary War hero, having served with Washington at Valley Forge, and had already begun to build a reputation as an outstanding state legislator and lawyer.

Marshall and Jefferson were second cousins, both descendants of the prominent Randolph family of Virginia, and, on the surface, they appeared to have much in common. Both revered their fathers, who had supervised educations that led them to study law with George Wythe at the College of William and Mary. But Marshall and Jefferson's shared bloodline did not make them friends or political allies. Unlike Jefferson, Marshall believed in a strong federal government, his Federalist convictions permanently formed during the Revolutionary War, when, as he later wrote, he considered "America as my country and Congress as my government."

Like Jefferson, Marshall was a big man, over six feet tall. He had piercing black eyes and dark, unkempt hair. His clothes appeared to be rumpled even when he had hardly worn them. He was immensely popular in Richmond, a hearty, gregarious fellow who liked to drink 
with his friends in the local taverns. When he addressed the convention in Richmond, his forensic skills had not fully developed; but he was already an accomplished lawyer who knew how to make an effective argument.

Marshall chose to meet Henry's core argument, that the Constitution was an invitation to monarchy, head-on. His opponent misread the document, he asserted. The Constitution provided for "a well regulated democracy" where no king, or president, could undermine representative government. His most sustained argument was saved for the defense of a federal judiciary. The future chief justice of the United States told the delegates that an independent federal judiciary was a necessary bulwark against an overreaching Congress. If Congress were to exceed its powers, said Marshall, it would be the duty of the judiciary to declare the action void.

Marshall's tone was conciliatory. He did not speak apocalyptically of dire results that would inevitably follow if the delegates rejected the Constitution. There might be "small defects," he conceded, but if the other delegates were convinced, as he was, "that the good greatly preponderates," then they should vote for ratification. And if the Constitution proved to be less than the framers hoped or the people deserved, there was ample provision for amendment.

Henry responded ruefully that Marshall was wrong in every particular of his argument. But the older man spoke of his antagonist without rancor. His opposition to Marshall's position, said Henry, did not diminish his "highest veneration and respect for the honorable gentleman." Henry's compliment underscored one of Marshall's greatest talents, his ability to earn the respect of his adversaries. Except, as we shall see, for Thomas Jefferson.

By the time Jefferson received the news that the Virginia delegates had voted, by a margin of eighty-nine to seventy-nine, to ratify the Constitution, he was fully supportive of Madison's successful efforts. But he was less satisfied with developments in Paris, where efforts for a peaceful resolution of the grievances against Louis XVI were foundering. By the winter of 1789 , it was clear that the nobles and clergy were exercising no moderating influence on the king, nor were they genuinely 
interested in pressing for financial and political reforms. In the spring, bread lines lengthened, tempers exploded, and the streets became ready incubators for violence. Jefferson did his part to accommodate the growing demands of the masses, collaborating with Lafayette to draft a declaration of rights that Lafayette introduced in the National Assembly. Even after the storming of the Bastille, Jefferson did not abandon his hope that governmental reforms could avoid the worst excesses of revolution.

In September, when Jefferson and his two daughters, Martha (nicknamed Patsy) and Mary (called Maria or Polly), packed for a sixmonth home visit, the National Assembly was still in session trying to draft a constitution, and the French Revolution was far from running its course. But the massive social and political upheaval, only dimly perceived a year earlier, was closer than Jefferson was yet prepared to concede. He remained optimistic that the recent chaos would ultimately redound to the lasting benefit of France and the world. More than ever, he was an unabashed Francophile. To the list of reasons for his affection, Jefferson could now add his admiration for the ideals of the incipient revolution. He believed that France's first halting steps toward republican government would spread from Paris to other parts of the European continent. And he was more convinced than ever that France was the United States' most important ally, perfectly positioned to serve as the necessary wedge to break the British stranglehold on U.S. trade.

Expecting to return to Paris in the spring, Jefferson had renewed his lease at the Hôtel de Langeac and had left all of his furnishings in place. When he and his daughters sailed on the Clermont for Norfolk, they nonetheless transported thirty-eight boxes and several trunks of possessions, as well as the carriage and harpsichord Jefferson had purchased in London. Jefferson's intention was to settle Martha and Maria permanently at Monticello, take care of important financial matters, and then return for the remaining two years of his ministerial term. But shortly after he arrived in Virginia, he was confronted with an unwelcome alternative. He received a letter from President George Washington inviting him to join the Cabinet as secretary of state. Jefferson much preferred to complete his tour in France, but he felt a loyalty to the nation's first president that he could not ignore. Soon after 
Jefferson received Washington's offer, Madison came calling, urging him to accept the Cabinet post. Before long, he was serenaded with praise from a committee of the local citizenry, an outpouring surely orchestrated by his friend Madison. Despite the subtle pressure, Jefferson kept his own counsel and waited until January to inform Washington that he would accept his offer.

The first Gabinet in American history was small in size, but not in intellectual firepower, thanks to the dominating presence of Jefferson and Secretary of the Treasury Alexander Hamilton. They were joined by Henry Knox, Washington's secretary of war; and his part-time attorney general, Edmund Randolph. Vice President John Adams was not considered a member of the Cabinet and did not attend their policy sessions.

Jefferson first met the thirty-five-year-old Hamilton in New York in the spring of 1790 , when both were newly appointed Cabinet members. Undoubtedly, Jefferson had learned something about Hamilton from Madison, who had collaborated with Hamilton (and to a lesser extent with John Jay, who would become the first chief justice of the United States) in writing The Federalist, the classic defense of the Constitution that was published after the Constitutional Convention. But nothing Madison could have told Jefferson would have prepared him for the tightly wound human dynamo whom Washington chose as secretary of the treasury.

Jefferson's and Hamilton's backgrounds could not have been more different. Jefferson's first memory was of being carried on horseback on a pillow by one of the family slaves. His father, Peter, a land surveyor and leader in his Albemarle County community, had left his son more than fourteen hundred acres of land. Hamilton was, literally, a poor bastard, born on the British West Indies island of Nevis to an unhappily married woman, Rachel Lavien, and a wandering, financially inept Scottish merchant, James Hamilton. He eventually emigrated to New York, where he distinguished himself as a brilliant special student at King's College (now Columbia University) and, later, as a practicing attorney in Manhattan. As compensation for his humble, illegitimate beginnings, it was later said, Hamilton was fueled 
by inexhaustible energy and ambition. He never seemed satisfied merely to accomplish a difficult task; he attacked it in the most dramatic fashion possible. That was the case when the five-foot-seven, slight Hamilton, as General Washington's field commander at Yorktown in 1781, leapt over a parapet ahead of his troops to assault a British regiment.

Hamilton's and Jefferson's political philosophies were as different as their personalities and backgrounds. Jefferson's primary loyalties were to states' rights, popular (if limited) sovereignty, and individual liberty. Hamilton was committed to a strong federal government. His convictions had been laid out in elaborate detail in the articles he wrote for The Federalist. As secretary of the treasury, he was determined to put his philosophical arguments into practice, consolidating the power of the newly constituted national government.

In his first month in office, Hamilton sent the First Congress his "Report on the Public Credit," a sweeping proposal for the federal government to assume over $\$ 75$ million in public debt. He recommended that the federal government accept responsibility not only for the United States' domestic and foreign debts under the old Articles of Confederation, but for an additional $\$ 25$ million of debt incurred by the states in prosecuting the Revolutionary War against Great Britain.

At first glance, Hamilton's proposal appeared to make the new federal government weaker, not stronger, because it would be saddled with an enormous public debt. But his ingenious vision looked beyond the short-term debt to the long-term gains that would accrue to the federal government. By drawing all financial obligations to the national government, Hamilton immediately stanched the centrifugal economic forces that had, in large part, doomed the Articles of Confederation. He also offered Congress an urgent reason to collect taxes for the federal treasury-namely, to help pay off the gigantic national debt.

Hamilton's proposal challenged some of the most cherished tenets of Jefferson's philosophy. Jefferson believed that America's destiny depended upon a traditional agrarian economy that was based on the hard work and democratic ideals of yeoman farmers. He deplored public indebtedness and paper currencies, and the Northern speculators who profited from both. Most of all, he feared the consolidation of power in the federal government. That had been his primary reserva- 
tion about the Constitution and remained so after its adoption. He conceded broad power to the federal government only in the sphere of foreign affairs. Domestically, he believed that the states represented the most efficacious governmental unit, in large part because they were closest to the people.

Although Jefferson viewed Hamilton's debt proposal warily, he was not prepared to oppose it. He did not want to appear negative toward his Cabinet colleague before they had yet had the opportunity to work together. There was opposition enough to Hamilton's plan, and it came most significantly from Madison, who had already made himself the most influential leader in the House of Representatives. Besides his general suspicion about the pull of Hamilton's program toward the federal government, Madison was particularly concerned that it would unfairly reward speculators who had bought government securities from poor farmers, tradesmen, and Revolutionary War veterans at a fraction of their par value, which, under Hamilton's plan, the federal government would pay off.

When his proposal bogged down in Congress, Hamilton approached Jefferson for help, asserting that the failure of the bill to pass would imperil the union. Despite his anxiety about Hamilton's proposal, Jefferson agreed to serve as a political power broker between the secretary of the treasury and Madison, arranging for them to meet at his residence on Maiden Lane in lower Manhattan to resolve their differences. By evening's end, the three men had struck a deal. Jefferson and Madison accepted Hamilton's plan for the federal government to assume the states' debts. In return, Hamilton agreed to work on their behalf to relocate the nation's capital to the Potomac after a ten-year interim period in Philadelphia. At the time, Jefferson was pleased with the agreement, thinking that it would ultimately benefit the agrarian Southern states, and particularly Virginia, which bordered on the Potomac. But Jefferson later admitted that it was the worst political decision he ever made, providing Hamilton with the first important victory in his drive to increase the power of the federal government.

Hamilton hardly paused after his initial success before proposing a second, equally bold financial innovation: the creation of a national bank of the United States. Great Britain was his economic model. Hamilton was impressed by the ambitious policies of the powerful 
British financial ministers and the essential role that the Bank of England played in providing credit to the national government. $\mathrm{He}$ anticipated that a national bank of the United States would serve the nation much as the Bank of England functioned in Great Britain. Responding to Hamilton's initiative, Congress passed a bill chartering the Bank of the United States.

This time, Secretary of State Jefferson did not pledge his cooperation with Hamilton but instead urged Washington to veto the legislation. Now fully alert to the treasury secretary's centralizing agenda, Jefferson contended that Congress could only do what was explicitly authorized by the text of the Constitution. And nowhere in that document, he maintained, was Congress given the authority to establish a national bank-not even under the seemingly open-ended "necessary and proper clause."* The bank was not absolutely necessary for Congress to exercise its constitutional authority. If the term "necessary" could be so loosely interpreted as to permit Congress to charter a national bank, Jefferson maintained, there would be almost no end to which ingenious minds might not torture the constitutional language. Under such a broad interpretation, Jefferson insisted, the federal government "would swallow up" all of the delegated powers of the states. And the framers surely did not intend to authorize Congress "to break down the most ancient and fundamental laws" of the states.

In his response, Hamilton made the argument that convinced President Washington. Hamilton maintained that the whole purpose of the "necessary and proper" clause was to give "a liberal latitude to the exercise of the specified powers." The phrase did not grant Congress independent powers, Hamilton conceded, but it did sanction the exercise of authority implied by their express constitutional powers. The relevant inquiry was whether the means selected by Congress was related to an end explicitly given to the legislature in the Constitution. And a national bank satisfied that constitutional standard, because it would facilitate Congress's ability to collect taxes, borrow money, regulate commerce, and raise and support armies, all powers explicitly

"Under Article I, section 8, of the Constitution, Congress is given the authority to tax, regulate commerce, borrow money, and raise and support armies, among other powers, and "to make all Laws which shall be necessary and proper" to implement those powers. 
granted to Congress. "If the end be clearly comprehended with any of the specified powers, and if the measure have an obvious relation to that end, and is not forbidden by any particular provision of the Constitution," Hamilton declared, "it may safely be deemed to come within the compass of the national authority."

After Hamilton bested Jefferson in the debate over the constitutionality of the national bank, the secretary of state viewed him as a dangerous enemy, not just of his philosophy but of the future of the republic. The two Cabinet members' breach widened further when Hamilton invaded Jefferson's official foreign-policy turf and, Jefferson believed, systematically undermined the secretary of state's initiatives. Their disagreements centered on U.S. relations with Great Britain. Hamilton considered Great Britain to be the United States' most valued trade partner, and the key to the future prosperity of the American economy. Jefferson's distrust of the British and disgust with their discriminatory trading policies were well known. As secretary of state, he was determined to do all in his power to shift the United States' trade away from Great Britain and toward his favorite foreign nation, France.

But at every turn, it seemed, Jefferson was frustrated by Hamilton in his design to end Great Britain's dominating presence in U.S. trade relations. The secretary of state prepared a report for Congress recommending that the U.S. give preferential treatment to nations that did not discriminate against American trade. France had made modest concessions to American imports; Great Britain had not. As a result, Jefferson concluded, there should be an adjustment in the tonnage duties imposed on foreign carriers to reduce the duties on friendly, nondiscriminatory nations like France. But the policy was never implemented-in large part, Jefferson suspected, because Hamilton had lobbied his allies in Congress to oppose it.

The final insult for Jefferson came in 1792, after he had begun negotiations with the British minister, George Hammond, to settle the outstanding differences of the two nations under the Peace Treaty of 1783. No progress had been made since Jefferson and Adams met with Lord Carmarthen in 1786. British creditors continued to demand payment from Americans for outstanding debts. The U.S. countered that British troops must relinquish their military posts in the old Northwest Terri- 
tory, and that there should be reimbursement for British troops' confiscation of slaves and other property during the war.

Hammond had taken the initiative in the negotiation, submitting a paper blaming the United States for every infraction of the treaty. Jefferson responded with a state paper of gigantic and elegant proportions. In 250 manuscript pages, a product of eight weeks of interviews with officials and research into the public record, the American secretary of state aggressively met each British charge with an explanation and a countercharge. It was an astounding diplomatic tour de force that stunned Hammond. Over dinner with Jefferson, the British minister said that the secretary of state's paper put matters in a different light, and that he would need further instructions from London. But before Jefferson could apply additional pressure on the British minister, Hamilton intervened, assuring Hammond that Jefferson did not speak for the administration and that his paper was an ill-conceived, regrettably anti-British attack. Given that critical knowledge of dissension within the Washington Cabinet, Hammond and his superiors at Whitehall felt no urgent need to respond to Jefferson's demands. Nothing came of the secretary of state's work; every outstanding issue from the peace treaty remained unresolved during the remainder of Jefferson's Cabinet term.

In 1792, Jefferson began to speak of "the heats and tumults of conflicting parties," dividing the Cabinet and Congress into the categorical "we" and "them." The "we" included Jefferson, Madison, and likeminded republicans who were committed to an agrarian-based economy that favored state sovereignty, popular democracy, and a closer trade relationship with France. The "monarchial federalist" opposition was led by Hamilton and, in Jefferson's eyes, was catapulting the nation toward economic and political disaster, consolidating political power in the federal government, building a huge national debt that primarily benefited Northern speculators, and binding the nation to the arrogant and discriminatory trade policies of Great Britain.

Relations between Jefferson and Hamilton spiraled downward, as the rhetoric of their partisans in the press escalated. The National Gazette, founded by Philip Freneau with the encouragement of both Madison and Jefferson, began to publish regular attacks on Hamilton as a dangerous consolidationist. Those attacks were answered by the 
Gazette of the United States, which openly assailed Jefferson's philosophy and his character.

The two antagonists eagerly joined the fray. Hamilton privately referred to Jefferson's foreign policy as "a womanish attachment to France and a womanish resentment against Great Britain." And in the pages of the Gazette of the United States, an article signed "An American" and written in the distinctive style of the treasury secretary accused Jefferson of secretly working to undermine public confidence in the government. Jefferson countered by telling the president that Hamilton's policies had poisoned public trust in the government and had led the people "to occupy themselves and their capital in a species of gambling" that was "destructive of morality." Later, he enlisted a young republican supporter, Virginia Congressman William Branch Giles, to introduce a series of resolutions on the floor of the House of Representatives condemning Hamilton's economic policies.

The president counseled moderation and understanding between his two most valued Cabinet members, but even the revered Washington was helpless to tamp down the raging controversy. When the armies of revolutionary France declared war on Great Britain in 1793, only ten days after King Louis XVI had been executed, Jefferson and Hamilton's arguments over foreign policy suddenly posed immediate dangers for the nation. Jefferson sided with France and urged the president to adopt a policy that recognized U.S. obligations to France under the treaty signed between the two nations during the Revolutionary War. Hamilton countered that preferential treatment of France would lead to war with Great Britain, a result to be avoided at all costs. Washington's answer to both men was an official proclamation of neutrality; this effectively favored Great Britain, Jefferson believed, since it took no notice of the U.S.'s 1778 treaty with France.

For more than a year, Jefferson had been telling President Washington that he wanted to retire from public service. He had long expressed his desire to return to private life. And after three years in the Cabinet, it was quite obvious to Jefferson that Hamilton had the president's ear and that his own advice was of decreasing importance. Jefferson's warnings of the dangers of Hamilton's economic policies had largely gone unheeded. To Jefferson, Washington's pattern was maddeningly familiar. The president patiently listened to the arguments of both 
Hamilton and Jefferson and then-invariably, it seemed-sided with his treasury secretary. That had been the case with the bank controversy, as well as most of Hamilton's other economic initiatives. And in Jefferson's mind, Washington held true to form in the debate over the U.S.'s neutrality policy.

Despite pleas from the president that Jefferson remain in the Cabinet, Jefferson announced in December 1793 that he was retiring from public life to attend to his farm and family at Monticello. Few believed him. Hamilton had already predicted that Jefferson would run for president.

With the indispensable organizational talents of Madison, Jefferson's republican message spread from Monticello through county organizations and a growing network of sympathetic newspapers. The president was spared criticism, but the policies of his dominant Cabinet member were not. It was time for the nation to return to the republican principles on which it had been founded. Domestically, that meant the rejection of Hamilton's monarchial economic policies. In foreign policy, the U.S. must stop mortgaging its future to the imperious British.

The Jay Treaty of 1794 provided Jefferson and his republican supporters with a ready campaign issue for the anticipated contested presidential election in 1796. Washington had sent Chief Justice John Jay to London to come to terms with a restive and not altogether friendly British government. The president's declaration of neutrality had momentarily placated Great Britain, but the increasingly debilitating war with France had made the British navy bolder in confiscating the cargoes on U.S. ships and impressing young American sailors into His Majesty's service.

Jay negotiated as if his diplomatic choices were extremely narrow: either sign a treaty with Great Britain that subordinated U.S. interests to those of His Majesty's government or risk open warfare. Jay chose the peaceful alternative, and Congress ratified the terms of the treaty. When Washington signed the Jay Treaty, Jefferson denounced the agreement as "nothing more than a treaty of alliance between England and the Anglomen of this country against ... the people of the United States." The French government was just as angry, accusing the U.S. of 
violating the terms of their 1778 treaty. Soon enough, France retaliated by seizing cargoes on American ships with the same abandon as the British appeared to be exercising under cover of the treaty.

The Jay Treaty became the political fault line between Federalists and supporters of Jefferson's newly formed Democratic-Republican party (known as Republicans). In Virginia, the treaty was greeted with widespread Republican condemnation, though there were pockets of support from outnumbered Federalists. The most prominent defender of the treaty in Virginia was John Marshall, now one of Richmond's most respected attorneys as well as a prosperous landowner. President Washington had been so impressed with Marshall's talents that he had offered him the position of attorney general, but Marshall had declined.

Although Jefferson began to take notice of Marshall, it was not the kind that could have pleased either man. After Marshall was reelected to the Virginia legislature in 1795, Jefferson wrote Madison that Marshall's hypocrisy ("acting under the mask of Republicanism") and his "lax lounging manners" had made him popular in Richmond. But Jefferson was confident that Marshall could not continue to fool the people once his true politics forced him to "come forth in the plenitude of his English principles."

Jefferson's old friend John Adams was his Federalist opponent in the 1796 presidential election. Though the two men were not as close as they had been during their diplomatic days in Europe, they still respected each other. And they agreed on at least one important subject: each despised Hamilton. Hamilton had retired from Washington's Cabinet in 1795 to return to the private practice of law in New York City but, nonetheless, retained great political influence. Adams represented the moderate Federalists, a fact that thoroughly alienated Hamilton, who wanted the Federalists to act more aggressively in consolidating federal power and openly supporting Great Britain in her war with France. Ironically, Jefferson treated his opponent, Adams,

"The concept of political parties in 1796 was a far cry from modern political organizations. Rather than rigidly disciplined organizations, Federalists and Republicans were loosely formed political alliances. 
more honorably than did Hamilton. The treasury secretary worked behind the scenes in support of Adams's running mate, Thomas Pinckney, with the hope that Pinckney might receive more electoral votes than Adams. In contrast, Jefferson let it be known that if, by chance, the election ended in a tie he would defer to Adams in the interest of a harmonious transition of power.

When Adams eked out a victory over Jefferson by three electoral votes, the defeated Republican candidate did not seem distraught or hostile to the new president. Having accumulated the second-highest number of electoral votes, Jefferson became the nation's vice president and pledged to cooperate with Adams, an attitude that was reciprocated by Adams. . One of President Adams's first gestures of reconciliation toward Jefferson was to ask the vice president to represent the United States on a diplomatic mission to France. Jefferson declined this appointment on the advice of Madison, who disapproved of such a cozy relationship between rival political leaders.

Undeterred by Jefferson's rejection, Adams was determined to encourage bipartisanship in his diplomatic approach to the settlement of the nation's differences with France. The president next proposed a bipartisan three-member commission to negotiate a treaty in Paris. Adams named Charles Cotesworth Pinckney, who was already in Paris, to the commission, as well as Elbridge Gerry, a moderate Federalist from Massachusetts and a close friend of Adams. As the third member of the delegation, the president wanted Madison (who had retired from the House of Representatives) to serve, but he refused. Adams's replacement for Madison was John Marshall, an appointment that would have momentous historic implications.

Two events in the late spring of 1797 changed the tenor of the political discourse between the controlling Federalists and Jefferson's Republicans. Adams, in response to what he considered France's hostile actions toward the U.S., called Congress into special session in May and

\footnotetext{
"The original version of the electoral college required two candidates, both theoretically standing for the presidency, though one candidate was generally acknowledged to be the preferred candidate for president. The candidate receiving the most electoral votes was elected president; the candidate with the second-highest number of votes became vice president. In 1796, when Federalists and Republicans each offered two candidates, the system allowed for the election of a president (Adams) and vice president (Jefferson) from different political alliances.
} 
delivered what Republicans termed a "war message" aimed at France's ruling Directory. For the first time since Adams's inauguration, Jefferson openly criticized the president, accusing him of unwarranted partisanship in his foreign policy. During the same month, a letter that Jefferson had written in 1796 to his old friend and Virginia neighbor Philip Mazzei was published. In the letter Jefferson made an apparent reference to Washington as one of the "men who were Samsons in the field and Solomons in the council, but who have had their heads shorn by the harlot England." The Federalists, Marshall included, never forgave Jefferson for defaming the great Washington.

Battle lines between the Adams administration and Jefferson's Republicans were now irrevocably drawn. The vice president viewed every Adams initiative with suspicion, particularly in the field of foreign affairs, convinced that the Federalists were intent on a permanent alliance with monarchial Great Britain. At just this time, Marshall and Gerry embarked on their diplomatic mission to Paris. The Richmond lawyer's leadership role in the negotiation with the French government marked the beginning of a conflict between Marshall and Jefferson that would profoundly affect American politics and constitutional law. 